\title{
CCRL2 wt Allele
}

National Cancer Institute

\section{Source}

National Cancer Institute. CCRL2 wt Allele. NCI Thesaurus. Code C51330.

Human CCRL2 wild-type allele is located within 3p21 and is approximately $2 \mathrm{~kb}$ in length. This allele, which encodes C-C chemokine receptor-like 2 protein, is involved in signal transduction and macrophage differentiation; however, an exact function has yet to be elucidated. 